\title{
Melatonin menurunkan berat badan tetapi tidak menurunkan kadar TNF- $\alpha$ pada tikus wistar jantan yang diberi minyak jelantah selama 28 hari
}

\author{
Anugrah Novianti ${ }^{1}$, Edi Dharmana ${ }^{2}$, Nyoman Suci Widyastiti ${ }^{2}$
}

\begin{abstract}
Backgound: Non Alcoholic Fatty Liver Disease (NAFLD) occurs when the intake and free fatty acid synthesis occurs more frequently than its oxidation and resecretion in the blood. Melatonin is a powerful antioxidant that can boost the synthesis of endogenous antioxidants in the body, suppress the inflammatory response and inhibit the formation of steatosis.

Objective: To analyze the effect of melatonin supplementation in reducing body weight andTNF- $\alpha$ levels in male Wistar rats were fed by waste cooking oil.

Methods: True experimental studyusing post-test only control group design. This study was done on 18 male wistar rats were divided into 3 groups : the positive control group $\left(P_{0}\right)$ was administrated waste cooking oil, the treated group 1 ( $\left.P_{1}\right)$ was administrated waste cooking oil and $5 \mathrm{mg} / \mathrm{kgBW}$ melatonin, and the treated group $2\left(P_{2}\right)$ was administrated waste cooking oil and $10 \mathrm{mg} / \mathrm{kgBW}$ melatonin for 28 days.Data analysis using One Way ANOVA test and followed by Tukey test to determine the most effective dose of melatonin.

Results: There was significant difference in body weightbetween $P_{2}$ group and $K_{0}$ group $(p=0,019)$ with the mean body weight difference was 19,167g lower than $K_{0}$ group. There was no difference in TNF- $\alpha$ levels between the three groups ( $p=0,155$ ).

Conclusion: Melatonin dose of $10 \mathrm{mg} / \mathrm{kgBWloses}$ body weight male Wistar rats have given by waste cooking oil for 28 days, but does not reduce TNF- $\alpha$ levels.
\end{abstract}

Keywords: non-alcoholic fatty liver, waste cooking oil, melatonin, TNF- $\alpha$ levels.

\section{ABSTRAK}

Latar Belakang : Penyakit perlemakan hati non alkohol atau Non Alcoholic Fatty Liver Disease (NAFLD) terjadi ketika asupan dan sintesis asam lemak bebas lebih banyak terjadi dibandingkan proses oksidasi dan resekresinya dalam darah. Melatonin merupakan antioksidan kuat yang dapat meningkatkan sintesis antioksidan endogen dalam tubuh, menekan respon inflamasi dan menghambat pembentukan steatosis.

Tujuan :Menganalisis pemberian suplemen melatonin dalam menurunkan berat badan dan kadar TNF- $\alpha$ pada tikus Wistar jantan yang diberi minyak jelantah.

Metode : True experimental dengan menggunakanpost-test only control group design. Penelitian ini menggunakan 18 ekor tikus, dibagi menjadi 3 kelompok yaitu kelompok kontrol positif $\left(P_{0}\right)$ diberi minyak jelantah, kelompok perlakuan $1\left(P_{1}\right)$ diberi minyak jelantah dan melatonin dosis $5 \mathrm{mg} / \mathrm{kgBB}$, kelompok Perlakuan $2\left(P_{2}\right)$ diberi minyak jelantah dan melatonin dosis $10 \mathrm{mg} / \mathrm{kgBB}$ selama 28 hari. Analisis data menggunakan uji One Way Anova dan dilanjutkan dengan uji Tukey HSD untuk mengetahui dosis perlakuan mana yang lebih baik.

Hasil : Ada perbedaan bermakna rerata berat badan antara kelompok $P_{2}$ dan $K_{0}(p=0,019)$ dengan selisih rerata berat badan kelompok $P_{2}$ sebesar 19,167 lebih rendah dari kelompok $K_{0 . T i d a k}$ ada perbedaan kadar TNF- $\alpha$ antar ketiga kelompok yang diberi minyak jelantah $(p=0,155)$.

Simpulan : Melatonin dosis $10 \mathrm{mg} / \mathrm{kgBB}$ menurunkan berat badan tikus wistar jantan yang diberi minyak jelantahselama 28 hari, tetapi tidak menurunkan kadar TNF- $\alpha$.

Kata kunci : Perlemakan hati non alkohol, minyak jelantah, melatonin, jumlah steatosis, kadar TNF- $\alpha$.

\section{PENDAHULUAN}

NAFLD (Non-Alcoholic Fatty Liver Disease) kini diketahui sebagai salah satu bentuk penyakit hati kronik di negara-negara berkembang dengan

1. Fakultas Ilmu Kesehatan, Universitas Esa Unggul,
Jakarta
anugrahnovianti@gmail.com)
2. Bagian Parasitologi, Fakultas Kedokteran, Universitas
Diponegoro, Semarang
3. Bagian Patologi Klinik, Fakultas Kedokteran,
Universitas Diponegoro, Semarang

prevalensi $10-24 \%$ dari seluruh populasi. ${ }^{1}$ Penelitian pada masyarakat urban Jakarta menunjukkan prevalensi NAFLD sebesar 30,6\% berdasarkan diagnosis ultrasonografi (USG). Sedangkan, data dari RSUP dr.Kariadi juga menunjukkan peningkatan prevalensi penyakit ini dari tahun ke tahun (20052009) dimana peningkatan prevalensi masing-masing per tahun adalah $4 \%, 4,5 \%, 5 \%, 6 \%$ dan $7 \%$. $^{2}$

Adipokin-adipokin seperti tumor necrosis factor $-\alpha(\mathrm{TNF}-\alpha)$, resistin dan angiotensin II memicu resistensi insulin dan inflamasi derajat rendah pada penderita NAFLD melalui jalur pensinyalan protein 
kinase seperti $c$-Jun NH2-terminal kinase-1 (JNK-1) dan jalur nuclear factor kappa $B$ (NF- $\mathrm{BB})$. Sebaliknya, bila jalur pensinyalan TNF- $\alpha$ ini dihambat, maka resistensi insulin dan NAFLD dapat dicegah. $^{2}$ TNF- $\alpha$ dikenal mampu memodulasi dan meningkatkan ekspresi sterol regulatory element binding protein-1 (SREBP-1c), yang secara transkripsional mengaktivasi seluruh gen yang diperlukan dalam proses lipogenesis dan terbukti memicu terjadinya perlemakan hati dibandingkan sitokin proinflamasi $N F-\kappa B$ dependent lainnya. ${ }^{3}$

Makanan berlemak atau digoreng merupakan makanan yang secara luas disukai oleh berbagai lapisan masyarakat dari segala tingkat usia di Indonesia. ${ }^{4}$ Sumber utama asupan lemak orang Indonesia berasal dari makanan yang digoreng (8090\%). ${ }^{5}$ Tingkat konsumsi minyak goreng juga dilaporkan mencapai lebih dari 2,5 juta ton per tahun, atau lebih dari $12 \mathrm{~kg}$ per orang per tahun. ${ }^{6}$ Minyak goreng bekas (jelantah) adalah minyak yang telah digunakan lebih dari dua atau tiga kali penggorengan.Pemanasan minyak seperti ini dapat mempercepat hidrolisis trigliserida dan meningkatkan kandungan asam lemak bebas (FFA) di dalam minyak. ${ }^{7}$ Konsumsi berlebihan minyak jelantah memicu pembentukan sitokin TNF- $\alpha$ yang bersifat inflamasi dan menghambat sekresi insulin. Hal ini disebabkan karena makrofag mudah keluar dari sel adiposit yang meningkat jumlahnya, selanjutnya terjadi peningkatan kadar TNF- $\alpha$ dalam darah. ${ }^{5}$

Melatonin merupakan suplemen antioksidan yang sangat potensial untuk mencegah dan menanggulangi NAFLD, karena mampu bekerja baik dalam sel maupun membran sel dibandingkan jenis antioksidan lain yang hanya mampu larut dalam air atau lemak saja. Melatonin memiliki banyak manfaat, tidak hanya berperan sebagai penangkal radikal bebas yang sangat kuat, pelindung sel tubuh terhadap Reactive Oxygen Species (ROS)dan Nitrogen Reactive Species (NRS), melatonin juga memiliki kemampuan dalam meningkatkan produksi glutation sebagai antioksidan yang dihasilkan tubuh, anti-inflamasi, anti-apoptosis/proliferasi ${ }^{8,5,9}$ Selain itu melatonin juga dapat menurunkan berat badan secara cepat, saat dengan meningkatkan produksi BAT dalam tubuh dan meningkatkan aktivitasnya untuk mengatur metabolisme energi dalam tubuh.

Tujuan dari penelitian ini adalah menganalisis pemberian suplemen melatonin dalam menurunkan berat badan dankadar TNF- $\alpha$ pada tikus Wistarjantan yang diberi minyak jelantah. Pengamatan dilakukan selama 28 hari dengan dosis melatonin $5 \mathrm{mg} / \mathrm{kgBB}$ dan $10 \mathrm{mg} / \mathrm{kgBB}$, dan akan dilakukan analisis lanjutan untuk mengetahui dosis melatonin yang terbaik.

\section{BAHAN DAN METODE}

\section{Pembuatan Minyak Jelantah}

Minyak jelantah dibuat dengan cara menggoreng singkong selama 6x proses penggorengan secara bertahap yang sebelumnya sudah dikupas, dicuci dan dipotong terlebih dahulu, sehingga menghasilkan minyak jelantah dari hasil sisa penggorengannya.Penggunaan singkong sebagai bahan pangan untuk menghasilkan minyak jelantah pada penelitian ini, karena singkong merupakan jenis golongan pangan sumber karbohidrat dengan kandungan asam lemak jenuh yang sedikit sehingga meminimalkan peningkatan jumlah asam lemak pada minyak goreng yang bukan akibat dari hasil penggorengan berulang. Singkong dan minyak ditimbang dengan perbandingan 1:2 dan dimasukkan ke dalam minyak yang telah dipanaskan terlebih dahulu dan digoreng hingga matang. Tenggang waktu satu penggorengan dengan penggorengan selanjutnya (sampai 6x menggoreng) 15 menit. Setelah proses ini selesai, kemudian dilakukan analisis perhitungan bilangan peroksida dan Thio Barbituric Acid (TBA).

\section{Hewan dan Perlakuan}

Tikus putih (Rattus Novergicus) jantan galur Wistar, umur 2-3 bulan, berat badan 200-225g dari Laboratorium Fakultas Farmasi UGM Yogyakarta.Tikus Wistar pada penelitian ini dibagi ke dalam tiga kelompok : kelompok kontrol positif $\left(\mathrm{P}_{0}\right)$ yang diberi minyak jelantah dosis $3,5 \mathrm{ml} / 200 \mathrm{gBB}$ dan plasebo, kelompok perlakuan $1\left(\mathrm{P}_{1}\right)$ yang diberi minyak jelantah dosis $3,5 \mathrm{ml} / 200 \mathrm{gBB}$ dan melatonin dosis $5 \mathrm{mg} / \mathrm{kgBB}$ dan kelompok perlakuan $2\left(\mathrm{P}_{2}\right)$ yang diberi minyak jelantah dosis $3,5 \mathrm{ml} / 200 \mathrm{gBB}$ dan melatonin dosis $10 \mathrm{mg} / \mathrm{kgBB}$.

Pakan standar Comfeed AD II dengan komposisi : Air $=$ Maks. 12\%, Protein Kasar = Min. $15 \%$, Lemak Kasar $=3-7 \%$, Serat Kasar $=$ Maks . $6 \%, \mathrm{Abu}=$ Maks 7\%, Kalsium $=0,9-1,1$, Fosfor $=$ 0,6-0,9.Plasebo yang diberikan pada kelompok $\mathrm{P}_{0}$ ialah aquades $1 \mathrm{ml}$, sedangkan dosis melatonin yang diberikan untuk kelompok $\mathrm{P}_{1}$ dan $\mathrm{P}_{2}$ masing-masing ialah $5 \mathrm{mg} / \mathrm{kgBB}$ dan $10 \mathrm{mg} / \mathrm{kgBB}$, dilarutkan dalam 1 $\mathrm{ml}$ aquades.

Pengambilan darah pada tikus dilakukan $1 \mathrm{x}$ di akhir penelitian sebanyak 2 cc melalui plexus retroorbitalis pada mata, tikus dianestesi terlebih dahulu, dipegang dan dijepit bagian tengkuk dengan jari tangan, kemudian mikrokapiler digoreskan pada medial canthus mata di bawah bola mata ke arah foramen opticus, darah yang keluar ditampung pada effendorf tanpa EDTA untuk tujuan pengambilan serumnya. 


\section{Pengukuran Berat Badan Tikus}

Berat badan tikus diukur setiap minggu pukul 8-9 pagi menggunakan timbangan digital elektrik.

\section{Pemeriksaan Kadar TNF- $\alpha$}

Kadar TNF- $\alpha$ diperiksa dari serum darah tikus menggunakan kit ELISA merk Raybio ${ }^{\circledR}$ Tech, Inc Parkway Lane, Suite 100, Norcross Georgia, USA.

\section{Analisis Statistik}

Perbedaan rerata berat badan dan kadar TNF$\alpha$ antar kelompok menggunakan uji one way Anova dilanjutkan dengan uji Post Hoc untuk mengetahui efek perlakuan dosis mana yang lebih baik.

\section{HASIL}

Hasil pengamatan pembuatan minyak jelantah memperlihatkan bahwa minyak goreng kelapa sawit sebanyak 3 liter yang dipanaskan dengan alat Deep Frying yang dilengkapi termometer, mulai bergejolak (siap untuk menggoreng) pada suhu $150^{\circ} \mathrm{C}$ dan bahan makanan (singkong) digoreng hingga matang membutuhkan waktu 3 menit. Hasil analisis bilangan peroksida dan Thio Barbituric Acid (TBA) disajikan tabel berikut :

Tabel 1. Hasil Analisis Bilangan Peroksida

\begin{tabular}{cccc}
\hline $\begin{array}{c}\text { Berat Sampel } \\
(\mathbf{g})\end{array}$ & $\begin{array}{c}\text { Volume } \\
\text { Titrasi }(\mathbf{m l})\end{array}$ & $\begin{array}{c}\text { Bil.Peroksida } \\
(\text { awal }) \\
(\mathbf{m E q} / \mathbf{1 0 0 0 g})\end{array}$ & $\begin{array}{c}\text { Bil.Peroksida } \\
(\text { akhir }) \\
(\mathbf{m E q} / \mathbf{1 0 0 0 g})\end{array}$ \\
\hline 5,045 & 5,15 & 102 & 108 \\
\hline
\end{tabular}

Tabel 2. Hasil Analisis Bilangan TBA

\begin{tabular}{cccc}
\hline $\begin{array}{c}\text { Berat Sampel } \\
(\mathbf{g})\end{array}$ & ABS & $\begin{array}{c}\text { TBA (awal) } \\
(\mathbf{m g M D A} / \mathbf{k g})\end{array}$ & $\begin{array}{c}\text { TBA (akhir) } \\
(\mathbf{m g M D A} / \mathbf{k g})\end{array}$ \\
\hline 10,06 & 0,1896 & 0,441 & 0,528 \\
\hline
\end{tabular}

Menurut standar baku mutu minyak goreng dari Badan Standarisasi Nasional (SNI 3741:2013) ${ }^{10}$, syarat mutu minyak yang baik memiliki bilangan peroksida maksimal $10 \mathrm{mEq} / 1000 \mathrm{~g}$. Hasil analisis ini menunjukkan bahwa minyak jelantah tersebut telah rusak dengan hasil bilangan peroksida mencapai 102$108 \mathrm{mEq} / 1000 \mathrm{~g}$. Selain itu, hasil analisis bilangan TBA yang menunjukkan semakin tinggi hasil analisis bilangan TBA maka semakin jelek mutu minyak tersebut. Analisis bilangan TBA pada minyak tersebut menunjukkan hasil bilangan TBA yang tinggi yaitu 0,441-0,528 $\mathrm{mgMDA} / \mathrm{kg}$

\section{Beda Rerata Berat Badan dan Kadar TNF- $\alpha$ Antar Kelompok}

Analisis efek perlakuan diuji berdasarkan rerata berat badan dan kadar TNF- $\alpha$ antar kelompok sesudah diberikan perlakuan. Analisis kemaknaan dengan uji One Way Anova yang tersaji dalam Tabel 3 menunjukkan rerata berat pada kelompok kontrol positif yang diberi minyak jelantah tanpa melatonin mengalami peningkatan berat badan yang lebih tinggi dibandingkan dengan kelompok kontrol yang hanya diberi pakan standar dan kelompok perlakuan 1 dan 2 yang diberi minyak jelantah + melatonin. Selain itu, terdapat perbedaan bermakna rerata berat badan antar ketiga kelompok yang ditunjukkan dengan nilai $(p<$ $0,05)$.

Tabel 3 juga menunjukkan tidak ada perbedaan bermakna rerata kadar TNF- $\alpha$ antar ketiga kelompok $(p>0,05)$. Tetapi hasil ini menunjukkan bahwa rerata kadar TNF- $\alpha$ kelompok kontrol $(78,14 \pm 3,73 \mathrm{pg} / \mathrm{ml})$ yang diberi pakan standar lebih rendah dibandingkan dengan kelompok kontrol positif $(126,53 \pm 4,22 \mathrm{pg} / \mathrm{ml})$ yang diberi minyak jelantah dengan selisih 48,39 $\mathrm{pg} / \mathrm{ml}$. Hal ini menunjukkan bahwa minyak jelantah yang melalui proses penggorengan lebih dari 5 kali pemakaian dengan bilangan peroksida $102-108 \mathrm{mEq} / 1000 \mathrm{~g}$ dan bilang TBA 0,441-0,528 mgMDA/kg dapat memicu proses inflamasi dan stress oksidatif dalam tubuh dengan meningkatkan kadar TNF- $\alpha$.

Analisis uji kemaknaan rerata berat badan dengan One Way Anova menunjukkan adanya perbedaan yang signifikan $(p<0,05)$, maka dilakukan uji lanjutan Tukey HSD untuk mengetahui dosis melatonin mana yang lebih baik menurunkan berat badan tikus. Hasil uji Tukey HSD menunjukkan dosis melatonin $10 \mathrm{mg} / \mathrm{kgBB}$ signifikan dlaam menurunkan berat badan tikus $(p<0,05)$ yag disajikan pada Tabel 4 di bawah ini. 
Tabel 3.Hasil Uji One Way Anova Rerata Berat Badan dan Kadar TNF-a Antar Kelompok Sesudah Perlakuan

\begin{tabular}{ccccc}
\hline Variabel & $\mathbf{P}_{\mathbf{0}}$ & $\mathbf{P}_{\mathbf{1}}$ & $\mathbf{P}_{\mathbf{2}}$ & $\boldsymbol{p}$ \\
\hline Berat Badan & $239,17 \pm 12,57^{(\mathrm{a})}$ & $226,50 \pm 6,34^{(\mathrm{a})}$ & $220 \pm 12,10^{(\mathrm{a})}$ & $0,002^{(\mathrm{b})}$ \\
Kadar TNF- $\alpha$ & $126,53 \pm 4,22^{\text {(a) }}$ & $101,40 \pm 1,11^{\text {(a) }}$ & $98,095 \pm 1,21^{\text {(a) }}$ & $0,155^{(\mathrm{c})}$ \\
\hline
\end{tabular}

Keterangan :(a) Variabel ditentukan berdasarkan mean \pm SD, ${ }^{(b)}$ Berbeda signifikan $(p<0,05)$ menurunkan berat badan setelah perlakuan 28 hari berdasarkan uji one way ANOVA, ${ }^{(\mathrm{c})}$ Tidak berbeda signifikan $(p>0,05)$ menurunkan kadar TNF $\alpha$ setelah perlakuan 28 hari berdasarkan uji one way ANOVA.

Tabel 4. Hasil Uji Tukey HSD Rerata Berat Badan Antar Kelompok

\begin{tabular}{ccc}
\hline Kelompok & $\Delta$ & $p$ \\
\hline $\mathrm{P}_{0}$ dan $\mathrm{P}_{1}$ & $12,667^{(\mathrm{a})}$ & $0,135^{(\mathrm{b})}$ \\
$\mathrm{P}_{0}$ dan $\mathrm{P}_{2}$ & $19,167^{(\mathrm{a})}$ & $0,019^{(\mathrm{c})}$ \\
$\mathrm{P}_{1}$ dan $\mathrm{P}_{2}$ & $6,50^{\text {(a) }}$ & $0,558^{(\mathrm{b})}$ \\
\hline
\end{tabular}

Keterangan : ${ }^{\text {(a) }}$ Selisih rerata antar kedua kelompok, ${ }^{(b)}$ Dosis melatonin $5 \mathrm{mg} / \mathrm{kgBB}$ tidak signifikan menurunkan berat badan tikus $(p>0,05),{ }^{\left({ }^{c}\right)}$ Dosis melatonin $10 \mathrm{mg} / \mathrm{kgBB}$ signifikan menurunkan berat badan tikus $(p<0,05)$.

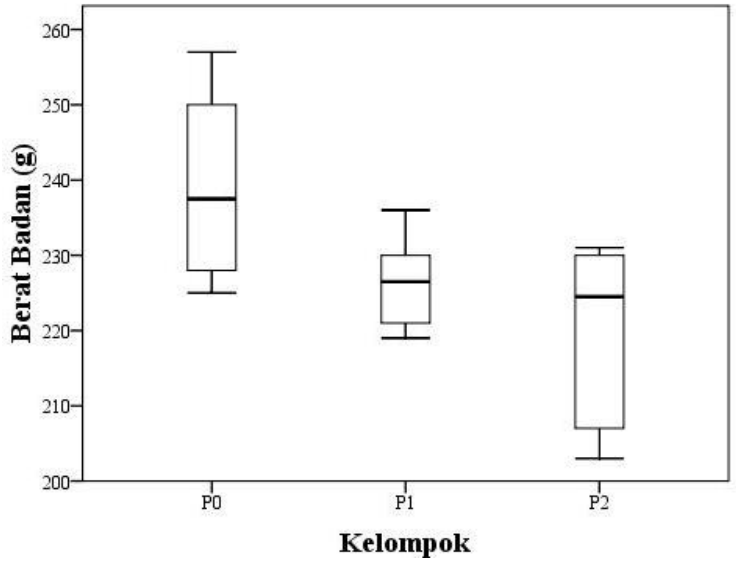

Gambar 1. Beda rerata berat badan kelompok kontrol positif $\left(\mathrm{P}_{0}\right)$ yang diberi minyak jelantah dan plasebo, kelompok perlakuan $1\left(\mathrm{P}_{1}\right)$ yang diberi minyak jelantah dan melatonin dosis $5 \mathrm{mg} / \mathrm{kgBB}$ dan kelompok perlakuan $2\left(\mathrm{P}_{2}\right)$ yang diberi minyak jelantah dan melatonin dosis $10 \mathrm{mg} / \mathrm{kgBB}$.

\section{Gambar 1. Beda rerata berat badan Antar kelompok}

\section{PEMBAHASAN}

Proses inflamasi dalam tubuh dapat diketahui melalui parameter peningkatan kadar TNF- $\alpha$. Hasil penelitian ini menunjukkan bahwa minyak jelantah yang melalui proses penggorengan lebih dari 5 kali pemakaian dengan bilangan peroksida 102$108 \mathrm{mEq} / 1000 \mathrm{~g}$ dan bilang TBA 0,441-0,528 mgMDA $/ \mathrm{kg}$ dapat memicu proses inflamasi dan stress oksidatif dalam tubuh dengan meningkatkan kadar TNF- $\alpha$. Hal ini sesuai dengan penelitian Susila Sastri tahun 2010 yang menunjukkan pemberian diet tinggi minyak sawit jelantah meningkatkan secara signifikan kadar sitokin TNF- $\alpha^{4}$.

Hasil penelitian ini menunjukkan bahwa tidak bermaknanya penurunan kadar TNF- $\alpha$ secara statistik pada kelompok perlakuan 1 dan 2. Hal ini mungkin disebabkan karena adanya proses inflamasi akut yang belum sepenuhnya dihambat oleh melatonin. Hal ini dapat disebabkan beberapa faktor seperti kurangnya waktu perlakuan melatonin dosis $5-10 \mathrm{mg} / \mathrm{kgBB}$ selama 28 hari dan kurangnya efektifitas suplemen melatonin tunggal dalam menurunkan kadar TNF- $\alpha$.

Oksidasi asam lemak dalam hepatosit merupakan penyebab utama peningkatan stress oksidatif dalam hepatosit yang menyebabkan terjadinya kerusakan DNA nukleus, disfungsi mitokondria dan pelepasan sitokin-sitokin proinflamasi NF- $\mathrm{kB}$ dependent (TNF$\alpha$, IL-6, IL-1ß). Tumor Necrosis Factor $\alpha$ (TNF- $\alpha)$ merupakan sitokin utama pada respon inflamasi akut terhadap bakteri gram negative dan mikroba lainnya. Infeksi yang berat dapat memicu produksi TNF- $\alpha$ dalam jumlah besar yang akan menimbulkan reaksi sistemik. TNF- $\alpha$ pada awalnya diidentifikasi sebagai mediator nekrosis tumor pada hewan coba yang diberi Lipopolysaccharide (LPS), hal ini dapat menyebabkan kematian sel, Disseminated Intravascular Coagulation (DIC) dan kerusakan pada jaringan. TNF- $\alpha$ memiliki efek biologis sebagai berikut : (1) Merangsang makrofag mensekresikan kemokin dan menginduksi kemoktaksis dan pengerahan leukosit. (2) Merangsang fagosit mononuclear untuk 
mensekresikan IL-1 dengan efek yang sama seperti TNF- $\alpha$. (3) Menginduksi apoptosis sel yang mengalami inflamasi. (4) Produksi TNF- $\alpha$ dalam jumlah besar dapat menurunkan kontraktilitas otot, tekanan darah atau syok yang menimbulkan kaheksia, gangguan metabolisme glukosa yang disebabkan karena penggunaan glukosa yang berlebihan oleh otot dan hati dan gagal untuk menggantikannya. ${ }^{11}$

Melatonin sebagai suplemen antioksidan pada penelitian ini belum mampu menekan respon inflamasi akut yang ditimbulkan dari aktivasi sitokin TNF- $\alpha$ tersebut. Penelitian Zaitone tahun 2011 tentang penggunaan kombinasi melatonin dengan berbagai jenis obat seperti Pentoxifylline dan Pioglitazone menunjukkan bahwa kombinasi melatonin dan obat khususnya Pentoxifylline terbukti lebih efektif menurunkan kadar TNF- $\alpha$ secara signifikan pada tikus yang diberi diet tinggi lemak dibandingkan dengan melatonin tunggal tanpa kombinasi atau kombinasi dengan obat Pioglitazone. ${ }^{12}$

Melatonin juga memegang peranan penting dalam meningkatkan produksi Brown Adipose Tissue (BAT) dalam tubuh dan meningkatkan aktivitasnya dalam mengatur metabolisme energi dalam tubuh. BAT berperan dalam proses pembakaran lemak dalam sel dan mempengaruhi tingkat metabolik secara signifikan. Seseorang yang memiliki kandungan BAT lebih banyak dalam tubuhnya mampu mengatasi kelebihan kalori dengan lebih baik dan resisten terhadap terjadinya obesitas. ${ }^{13}$

Penelitian lainnya oleh Faruk Serin tahun 2013 tentang pemberian kombinasi suplemen melatonin dan resveratrol menunjukkan peningkatan perbaikan sel hati pada tikus Wistar yang diberi Carbon Tetrachloride (CCL4) dan mengalami fibrosis ${ }^{14}$. Hasil-hasil peneltian ini menunjukkan bahwa penggunaan melatonin yang dikombinasikan dengan obat atau suplemen antioksidan lain seperti resveratrol menunjukkan hasil yang lebih efektif dalam menurunkan kadar TNF- $\alpha$ dan fibrosis hati pada tikus percobaan dibandingkan dengan penggunaan melatonin tunggal tanpa kombinasi obat dan suplemen antioksidan lain.

Kombinasi melatonin dan antioksidan lain seperti resveratrol dapat bekerja sinergis dalam mempengaruhi aktivitas sitokin proinflamasi melalui penghambatan jalur aktivitas Nuclear Factor Kappa $\beta$ $(\mathrm{NF}-\kappa \mathrm{B})$. Penghambatan aktivitas pensinyalan NF- $\mathrm{BB}$ mampu menekan pelepasan sitokin proinflamasi TNF$\alpha$ yang disekresikan sel hepatosit yang mengalami inflamasi. Selain itu, kemampuan antioksidanantioksidan ini yang kaya akan elektron positif dapat berfungsi sebagai donor elektron positif yang lebih kuat dan berikatan langsung dengan DNA mitokondria dan menjaganya dari kerusakan, kombinasi antioksidan ini juga berperan dalam aktivasi enzim catalase (CAT) dalam menangkal berbagai serangan ROS. ${ }^{15}$

\section{SIMPULAN}

Melatonin dosis terbaik $10 \mathrm{mg} / \mathrm{kgBB}$ menurunkan berat badan tikus wistar jantan yang diberi minyak jelantahselama 28 hari, tetapi tidak menurunkan kadar TNF- $\alpha$.

\section{DAFTAR PUSTAKA}

1. AV, Sey.Nonalcoholic Fatty Liver Disease : Epidemiology and Diagnosis. E-Liver Online. 2004, Vol. 1, 1-5.

2. Hasan I, Gani RA, Machmud R. Prevalence and Risk Factors For Nonalcoholic Fatty Liver in Indonesia. J Gastr Hepatol. 2002.Vol. 17, 154.

3. Seo YY, Cho YK, Bae JC. Tumor Necrosis Factor- $\alpha$ as a predictor for the Development of Nonalcoholic Fatty Liver Disease : A 4-Years Follow-Up Study. Endocrinol Metab. 2013. Vol $28: 41-5$.

4. Sastri S. Perbedaan pengaruh diet tinggi minyak sawit segar dengan minyak jelantah terhadap lemak dan TNF- $\alpha$ darah tikus. Majalah Kedokteran Andalas. 2010. Vol.34. No.1.

5. Sartika RAD. Pengaruh asam lemak jenuh, tidak jenuhdan asam lemak trans terhadap kesehatan. Jurnal Kesehatan Masyarakat Nasional. 2008 ;2(4):154-60.

6. Aisyah S, Balqis U, Karunia E. Histopatologi Jantung Tikus Putih Akibat Pemberian Minyak Jelantah. Jurnal Medika Veterinaria. 2014. Vol 8 (1).

7. Chowdhury I, Sengupta A, Kumar S. Melatonin : Fifty Years of Scientific Journey from the Discovery in Bovine Pineal Gland to Delineation of Functions in Human. Indian Journal Of Biochemistry and Biophysics. 2008. Vol 45, pp. 289-304.

8. Lingga L.The Healing Power of Antioxidant : Mengenal Lebih Jauh Sumber Antioksidan Unggulan. Jakarta : Elex Media Komputindo. Hal : 343-45. 2012.

9. Pevet P. Melatonin in animal models. Dialogues in Clinical Neuroscience. 2003. Vol 5, No. 4.

10. Badan Standarisasi Nasional. Minyak Goreng. 2013. Jakarta : BSN. 134619320/SNI-3741-2013Minyak-Goreng.pdf.

11. Kumar S, Balakrishnan V. Role of Cytokines in the Pathogenesis of Non-Alcoholic Fatty Liver Disease. Ind J Clin Biochem. 2011. Vol. 2, 202-09

12. Zaitone Sawsan, Neven H, Naglaa El-Orabi, ElSayed El-Awady. Pentoxifylline and melatonin in combination with pioglitazone ameliorate 
experimental non-alcoholic fatty liver disease. Eur J Pharmacology. 2011. Vol 662 (1-3) : 70-7.

13. Reiter RJ, Tan DX, Terron MP, Flores LJ, Zbigniew C. Melatonin and its metabolites: new findings regarding their production and their radical scavenging actions. Acta Biochimica Polonica. 2007. Vol. 54 (1) : 1-9.

14. Serin Faruk, Ertukler M, Gul Mehmet, Yigitcan Birgul. Investigating the effects of melatonin and resveratrol agents on non alcoholic fatty liver disease. Academic World Education and Research Center. Vol 3 (2013) : 1446-53.

15. Tan DX, Chen LD, Reiter RJ, Poeggeler B, Manchester LC. Melatonin: a potent, endogenous hydroxyl radical scavenger. Endocr J. 1993. Vol 1 (4) : 57-60. 